\title{
THE GREEK MONASTERIES IN SOUTH ITALY. IV.
}

\author{
THE LIBRARIES OF THE BASILIAN MONASTERIES.
}

IT has been shewn that Nilus of Rossano and his followers were skilful scribes and energetic students, though it is doubtful if as much can be said of the other Greek monks of South Italy at that period.

In the Norman period this literary spirit was kept up, and considerable libraries were founded in several monasteries. The chief ones were of course in those monasteries which were the largest and richest. We cannot trace the fortunes of them all, but we can piece together the outlines of the history of the libraries of S. Nicholas of Casola, and of S. Mary's of Patira from their beginning up to their dispersal, and we meet with other libraries at later points in their history, though we have no definite information as to the way in which they were collected.

The points, then, which call for consideration are:-

(1) The History of the Foundation of the Libraries.

(2) The Character of the Handzeriting employed in the various Scriptoria.

(3) The History of the Dispersal of the Libraries

These three points must be dealt with in order.

(1) The History of the Fonndation of the Libraries. As was said above, we have no knowledge on this point except so far as the libraries of S. Nicholas of Casola and S. Mary of Patira are concerned.

The history of the foundation and prosperous period of the library of S. Nicholas of Casola is as follows.

It was founded by Nicholas of Otranto, the third abbot, who ruled the convent from I $153^{-I}$ Igo. De Ferrariis tells us that Nicholas collected MSS from every part of Greece, and spared 
no expense to obtain a fine library. He also encouraged the monks in the monastery to add to the collection which he formed. This is shewn from his Typicon in the Turin MS $(217 \mathrm{~b}$, iii 27), which seems to have been especially designed to encourage the literary spirit and the careful preservation of the library ${ }^{1}$. Penance is enacted for any one who borrowed a book and left it open. Severe penalties were to be inflicted on a careless scribe who did not copy accurately, who dirtied his exemplar, or broke his pen. Gossiping in the library was especially forbidden, and when at the close of the day the monks retired to their cells, they were bidden to read, or else weep for their sins.

The Turin MS also gives us some idea of the contents of the library, though not a complete catalogue. Gospels, Psalters, and liturgical books are the chief works mentioned, but there were also copies of Aristotle and Aristophanes ${ }^{2}$, while it is probable that it was from this source that Bessarion obtained his copy of Quintus Calaber, and of the Rape of Helen.

The library so richly endowed naturally became a centre of Greek learning. 'Whoever ${ }^{3}$ ', says De Ferrariis, ' wished to work at Greek literature, was given teachers, lodgings, and the greater part of his board without any payment.' More than this, it was a lending library for students in the district. The Turin MS is full of notes which mention that MSS have been lent to various strangers. These notes have been collated by P. Cozza Luzi, who gave his translation to Mgr. Batiffol. It is to be found in the latter's L'Abbaye de Rossano, p. 125. Such is the history of the foundation of the library of S. Nicholas of Casola, and of the days of its prosperity.

The history of the library of S. Mary of Patira is similar, but except for its foundation less well preserved. It was founded by Bartholomew together with the monastery, for, finding that the monks had not a sufficiency of MSS of the Scriptures, he weint to Constantinople and made a collection of MSS and pictures. It is perhaps not too hazardous to guess that he then obtained the purple and silver manuscript of the Gospels known

1. Melanges d'A Archéologie et d' Histoire 1886 p. 187 .

2 Probably the one now in St. Mark's, Venice; cf. Mr. T. W. Allen's Introduction to the facsımile edition of this MS.

- De Sttu lapygrae p. 45.

- $A$. SS., Sept. viii p. 821 c. 
as $\Sigma$, one of a group of MSS of the sixth century which includes also $\mathrm{N}, \mathrm{N}_{2}, \Phi$, and is generally held to come from Constantinople ${ }^{\mathbf{1}}$. This is all that is known of the foundation of this monastery, and we have no knowledge of its further history until the time of its dispersal in the sixteenth century. It may have been-probably it was-a centre of learning for the region of Sila, as S. Nicholas of Casola was for the district of Otranto and the heel of Italy generally, but there is no evidence of the fact, nor have we until a late period any knowledge of its contents.

This information about the foundation of the Greek libraries of South Italy is not very great (and it only concerns two monasteries); but it is sufficient to enable us to lay down the general proposition that their foundation was due partly to the multiplication of manuscripts by native scribes, and partly to the importation of MSS from other parts of the Levant, especially perhaps from Constantinople.

It is a possible conjecture that the latter cause operated especially in the case of the monasteries dealt with above, and perhaps this is supported by the fact, which is shewn in the next section, that the scribes of Rossano and Casola used to copy the style of the Constantinopolitan writers rather than the school of calligraphy already existing in South Italy.

(2) The Handwriting employed in the various Scriptoria. I have already mentioned that Nilus and his friends adopted a style of handwriting which was influenced by the Lombardic or Beneventine type of Latin manuscripts. It would be natural to expect that this type of handwriting should be found in the manuscripts written in the Basilian monasteries of South Italy in the following centuries. This expectation is partly fulfilled, partly falsified.

It is fulfilled in the case of MSS which come from monasteries which were not under the direct influence of Bartholomew and his friends; it is largely falsified in the case of MSS which come from the libraries which he founded.

Mgr. Batiffol ${ }^{2}$ is the chief source of information on this point,

1 See Codex Purpureus Petropolitanus by A. E. Cronin in Texts and Studies, a paper on Codex Rossanensis $(\Sigma)$ in Studia Bıblica, and a note on $\mathrm{N}_{2}$ (Par. Gr. Suppl. 1 286) in Notices et Extratts Tom. xxxvi by M. Omont.

2 L'Abbaye de Rossano p. $9^{2}$ ff. 
though he does not point out the importance of the facts which he gives.

He quotes twenty-three MSS of the Norman period. Of these he finds the Greco-Lombard or, if I may so call it, the hand of the school of Nilus, in Cod. Vat. Gr. 2008, and in Cod. Neapol. II c. 7, which were written at S. John the Reaper, of Stilo, in I 102 and II 59 respectively; also in Cod. Vat. Gr. 2029, which was written at S. Elias of Carbo in $\mathrm{IO}_{3}$ (and there are traces, though less obvious, of the same type in Cod. Crypt. A. B. IO, written by Euthymius at Carbo in II3I); also in Cod. Vat. Gr. I22I, which was written in II 54 for the Abbot

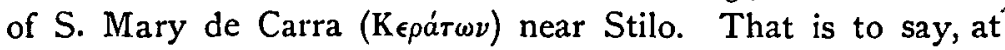
Carbo, at Stilo, and at S. Mary's de Carra near Stilo we have the calligraphy of the school of Nilus; but in the other monasteries, S. Mary's of Patira, its sister foundation S. Salvator of Messina, at S. Nicolas of Casola, and at S. Peter's of Arena, this type of handwriting does not make its appearance. Instead of it we have an imitation of the ordinary Constantinopolitan hand and style of ornamentation. This is surely to be attributed to the influence of the importations by Bartholomew and probably Nicholas, which set the fashion to the scribes.

Such a theory is, of course, at present only a speculation; but it seems to be that which is naturally suggested by the facts. If it be supported by future investigation it is not without importance, for there are many MSS of the twelfth century written in the hand of the school of Nilus which are. without any notes fixing their provenance. If we could say with certainty that these manuscripts come from Carbo, or Stilo, or some smaller house dependent on them, the gain to our knowledge would be considerable. It would, for instance, be a most valuable factor in determining the provenance of the Ferrar group, all of which are written in this style of hand, except Cod. 69, which is later than the others ${ }^{1}$.

Whether it will ever be possible to distinguish from Byzantine copies the MSS written in imitation of the Constantinopolitan hand, is a more doubtful question. In some cases probably it will be; for the scribe is clearly copying a type of MS which

\footnotetext{
${ }^{1}$ Codd. Evan. I3, 124, 69, 346, 543, 788, 826, 828, v. L'Abbé Martin Quatre mss. importants, and Rendel Harris Researches into the Ongin of the Ferrar Group.
} 
is not his own, and writes much worse than the true Byzantine. For instance, no one could possibly mistake Cod. Laur. Athous ${ } \mathrm{O}_{4}$ for a Byzantine MS, even if the pictures in it did not betray it $^{1}$; yet it would be hard to mention any single detail in which it differs from a MS from Constantinople. On the other hand; I have seen many MSS at Messina and in the Basilian collection in the Vatican which it would be impossible to surpass for elegance and beauty. Are these all importations? At present it is impossible to say, but there seems to be no reason why the question should remain permanently unanswerable.

(3) The History of the Dispersal of the Libraries. There is little doubt that for many years before the dispersal of the libraries there was a continual small waste of manuscripts, which were sold to collectors for inadequate sums, much as manuscripts on Mount Athos or Mount Sinai were sold (if they were even sold!) to Curzon and Tischendorf; but this is a process which it is almost impossible to trace, except by some lucky accident. The dispersals of MSS which are important, and which one ought to be able to trace, are those which are made en bloc, or in considerable numbers at a time.

The first person who seems to have recognized that it would be well to acquire and remove the libraries in South Italy was Cardinal Bessarion.

According to Valentinelli,the historian of the Biblioteca Marciana at Venice, he acquired almost the whole of the library of S. Nicholas of Casola about the year 1460 , and made it the nucleus of the magnificent collection of Greek MSS which he left to S. Mark's. The remainder of the library of S. Nicholas was destroyed by the Turks in 1481 , when they sacked the monastery. The whole therefore of the library of S. Nicholas, so far as it exists at all, is still to be found at S. Mark's, for the Marciana has never been dispersed. At the same time it must be remembered that in the sixteenth century the library of S. Mark's was very carelessly managed, and many of Bessarion's MSS disappeared. A threat of excommunication obtained the restitution of many of them, but some, no doubt, of the volumes were never returned, and must be sought for in other libraries. An account of the matter and its connexion with Mendoza is

1 Cod. Evan. Ioy 1, v. J. T. S. vol. i no. 3. The Italian orgin of Codex Bezae.

VOL. $\mathrm{V}$. 
to be found in Ch. Graux's Essai sur les origines du fonds grec de l'Escurial', p. 182.

The reconstruction of the catalogue of the library of S. Nicholas has never been seriously attempted; but I see no reason why it should not be made with, at least, the same degree of partial success that has attended Mgr. Batiffol's efforts in the case of the library of S. Mary of Patira at Rossano.

It would be necessary first to make a list ${ }^{2}$, of all the books mentioned in the Turin MS, and then to examine Bessarion's MSS at Venice. I cannot believe that there are no notes in any of the Casola MSS which would betray their origin. A library which was used for working in must have had some system of numeration, and this has surely left some traces behind. Even if the name of the monastery were not found, the task would not be necessarily hopeless. For instance, there is only one vellum $^{3}$ MS of Aristophanes in the Bessarion collection. It is an obvious conjecture to suggest that this is the Aristophanes which was at $\mathrm{S}$. Nicholas of Casola. Once a start was made in this way, it would be possible to do more; identity of handwriting, peculiarities of numbering and arrangement of quaternions, and many apparently insignificant details, would soon begin to assume importance and intelligibility.

Such work has been done with some success for the Laudian collection of Latin MSS in the Bodleian Library; why could it not be done for the Bessarion MSS from S. Nicholas of Casola in the Biblioteca Marciana?

In the fifteenth century, then, the library of S. Nicholas of Casola was taken to Venice, and must be looked for in the Biblioteca Marciana.

The other libraries of South Italy waited until the seventeenth century before they were bodily removed to more cultivated surroundings; but during the intervening period, they were gradually being dissipated and absorbed into other collections. It was the time when various great libraries were being founded. Lorenzo the Magnificent, the King of France, Cardinal Sirleto,

1 Biblotheque de $l$ 'Ecole des Hautes Etudes fasc. 46.

${ }^{2}$ I am not sure whether the list given in L'Abbaye de Rossano p. I25 $\mathrm{f}$ is exhaustive; I believe that it is not.

- Recently published by the Hellenic Society, with an introduction by Mr. T. W. Allen. 
Diego de Mendoza, Paez de Castro, and others, were collecting MSS. The last-named has left an interesting account, written about 1560 , of the way in which the collections were $\operatorname{made}^{1}$ :-

'Tres plaças principales ay en Italia, de donde han salido muchas librerias, assi la del Rey de Francia como de otros, que son Roma, Venezia y Florencia. De Levante se traian mui buenos libros mui escogidos en poco tiempo. En los reynos de Sicilia y Calabria ay muchas abadias y monasterios, que traian copia grande de libros griegos $y$ no se aprovechan d'ellos, antes se pierden por mal tratamiento y se roban de personas particulares. Yo vi, estando en Roma, que los mesmos Abades y Archimandritas traian muchos libros a presentar a Cardenales y otros a vender.'

It is impossible to do more than collect a few scattered traces. of this process of collection from the South Italian libraries; but these few are enough to shew to what an extent the libraries of Europe, especially of Italy and Spain, have been indebted to Calabria and the adjoining districts.

Perhaps the earliest account which we have is the story. of Janos Lascaris, who was employed by Lorenzo the Magnificent to collect manuscripts for the Medicean library at Florence.

Lascaris was a follower of Bessarion who entered the service of Lorenzo at the Cardinal's death in 1472 . He was brought to Rome by Leo $X$ in ${ }^{1} 5^{1} 3$, and in ${ }_{15}{ }^{1} 8$ went to Paris, where he assisted in the organization of the library at Fontainebleau, being appointed Maître de la Librairie. In 1534 he returned to Rome, to the service of Paul III, and died in 1535 . He used to make journeys to Calabria, Sicily, and Greece in search of MSS ; and by great good fortune a partial account of one of these journeys is preserved in Cod. Vat. Gr. I412. This has been published in $188_{4}$ by K. K. Muiller in the Centralblatt für Bibliothekswesen p. $333 \mathrm{ff}$. It gives us an account of a journey made on behalf of Lorenzo, during which he went to Corfu, Thessalonica, Constantinople, Mount Athos, and South Italy ${ }^{2}$; and he mentions that in Apulia he obtained MSS of Scholia on the division of the Staseis (long lections of the Psalms and Gospels), ancient Scholia on certain tragedies of Euripides, on Hermes Trismegistos, and fourteen others.

1 Le fonds grec de $T$ Escurial p. 28.

Op. cit. p. 402.

02 
In Corigliano ${ }^{1}$ he obtained from the priest George copies of the Magnum Etymologicum, of the writings of Nicholas of Otranto, of Coluthus's Rape of Helen, of Truphidorus's Sack of Troy, and three others; while at Monte Sardo, a dependency of S. Nicholas of Casola, which was no doubt impoverished by the loss of the great abbey, recently destroyed by the Turks, he obtained eight MSS, including copies of Aratus and Aristotle.

This collecting work of Lascaris for Lorenzo is no doubt typical of many other journeys by himself and by others; and Paez de Castro ${ }^{2}$, in the memorial quoted above, urges Philip II of Spain to send agents to Italy to exchange Latin printed books for Greek MSS, a transaction, he says, which would be good for all parties, and a great saving of money. He does not say anything about exchanging Latin MSS; but one cannot help thinking that it was in this way that Cod. C of the Vulgate, which was written in Spain, came to La Cava, though it is so beautiful a copy that one is afraid to press the suggestion that any collector would give it in exchange.

Probably Paez de Castro was not speaking without the knowledge that a Spanish collector had already done what he advised.

The earliest source of the Escurial library is the collection of Gonzalo Perez, which was acquired by the king. Antonio Perez ${ }^{3}$, in a letter to a friend, says that this collection was partly inherited from the Duke of Calabria who died at Valencia :... 'Otra parte era de libros de mano griegos muy antiguos que mi padre fué recogiendo en su vida y en el curso de su fortuna de abadias de Sicilia y de otras partes de Grecia.'

M. Ch. Graux has been unable to reconstruct the library of Gonzalo Perez, but he points out six MSS in the Escurial which probably belonged to it ${ }^{4}$, of which one ( $\Omega$ III 4 ) comes from

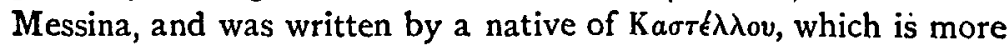
probably a Sicilian or Calabrian village than Castile (as M. Graux suggests), and another ( $\Phi$ I I) at least came to Spain from a Calabrian library. It is a MS of the eleventh or twelfth century, and has a note in Latin of the thirteenth or fourteenth century which mentions an abbot 'de Calabra'. M. Graux thinks that this is a mistake for de Calabria. I suggest that it is a village

1 Op. cit. p. ${ }_{403}$.

3 ibid. p. 34 , note 2.
2 Le fonds grec de l'Escurial p. 28.

'ibıd. p. 38 . 
named Calabra in the Basilicata, which is often mentioned in the charters of S. Elias of Carbo.

These are the only MSS which M. Graux notices as certainly drawn from the libraries of South Italy. There can be little doubt that an examination of the Escurial with attention to palaeography, and especially to the peculiarities of the School of Nilus, would add to the number.

The work of collecting MSS from South Italy also went on in Venice. The great collectors here were the Dandolos. The Dandolos were the hereditary 'proxeni' 1 of the French ambassador, and were famous for their wealth, influence, and culture. Marco appears to have begun the foundation of a library of Greek MSS, and Matteo greatly enriched it. One would have expected this library to contain MSS from South Italy; and although M. Graux does not mention any, it is almost certain that this expectation is not falsified by facts, for both the MSS of the Gospels, which were numbered 79 and 89 (or 80 ) in his catalogue, now numbered $\Psi$ III, 5 and $\Upsilon$ II, $8^{2}$ in the Escurial, contained

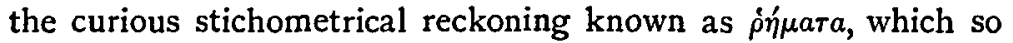
far as is known is not found except in South Italian MSS. It is found in twenty-three MSS, of which thirteen are in the hand of the School of Nilus, while the rest, so far as they have been examined, are of doubtful type, but cannot be said to be not South Italian. This gives, in the absence of more definite information, considerable support to the probability that the Dandolos drew on the libraries of South Italy for their collection of Greek MSS.

One would have expected the Dandolo library to be in S. Mark's. But it is not. At some unknown date it was purchased for the Escurial, where it still is. M. Graux has reconstructed it, on p. 109 of his book.

In this way MSS from South Italy were taken to the Escurial, to Florence, and to Venice. As one would naturally expect, they were also brought to Rome ${ }^{3}$. Cardinal Sirleto in ${ }_{15}^{6} \mathrm{I}$

1 Le fonds grec de IEscurial p. 125.

2 There is some mystery about this MS. M. Graux says it is Dandolo's 89 and that 80 is lost ; but Moldenhauer, who collated parts of it, says it is 80 . Again, M. Graux says that it is thirteenth century and contains the writings of Basil, Is it possible that there are two MSS numbered V. I I $\delta$ ?

3 Batiffol La Vaticane de Paul III et Paul V, and L'Abbaye de Rossano p. 40. 


\section{I98 THE JOURNAL OF THEOLOGICAL STUDIES}

obtained a catalogue of the MSS at S. Mary's of Patira (now unfortunately lost), and as he was then the Protector of the Basilian monks he had no difficulty in bringing or taking any volume which he wanted. For instance, in 1582 he mentions that there is at S. Mary's of Patira a copy of Hippolytus's tract against Noetus the heretic ${ }^{1}$. Three years later this MS was in Sirleto's possession, and is now in the Vatican (Cod. I43I).

Gradually the cardinal obtained a fine collection ${ }^{2}$. He employed agents all over the Levant, and even supplied them with lists of MSS which he desired to possess. He was not the only collector in Rome whose collection can still be roughly traced; but before going on to consider another eminent bibliophile it will be well to trace the outlines of the history of Sirleto's collection ${ }^{3}$.

At his death Philip II wished to buy his library en bloc for the Escurial, just as he bought the collection of Gonzalo Perez, and his offer (289 crowns for ninety-one MSS) is preserved in Cod. Barber. xxxiv, 107 ; but the transaction was prevented by the Vatican librarian Cardinal Carafa, who bought thirty-five selected MSS. These are all marked 'Emptum ex libris Cardinalis Sirleti', and two at least come from S. Mary's of Patira ${ }^{4}$ : (I) Cod. Vat. Gr. 143I, a collection of canons, made according to Mai by a Monophysite, and containing the tract of Hippolytus against Noetus. This is a MS of the twelfth century. (2) Cod. Vat. Gr. $145^{6}$, a palimpsest of the tenth century, containing the Onomasticon of Eusebius.

The rest of the library was bought in 1588 by Cardinal Colonna for 14,000 crowns. At his death a lawsuit led to the sale of his library, which was bought by Duke Altemps in I6II for 13,000 crowns, but 100 MSS were given by him to Pope Paul V.

Fifty years later the Altemps family began to sell the library, and many MSS were bought by Mabillon for the library of Louis XIV. I do not know whether these MSS have been traced ; they may perhaps be identified, among other things, by the binding, boards of cypress wood stamped with the arms of the Altemps, a golden stag on a red field, surmounted by a -crowned helmet.

In 1689 Pope Alexander VIII purchased the remainder of the

\footnotetext{
1 La Vattcane p. 54 .

s ibid. p. 52 ff.
}

ibud. p. $3^{8}$ f.

ibid. p. $53 \mathrm{f}$. 
collection and placed it in the palace of the Ottoboni, where it remained until 1740, when Benedict XIV bought the whole of the Ottobonian library.

Thus, after so many changes of ownership, the Sirleto MSS came into the Vatican library and joined the thirty-five selected MSS which had been already brought there by Cardinal Carafa. We may therefore expect to find a considerable number of South Italian MSS among the Ottobonian $\mathrm{MSS}^{\mathbf{1}}$ in the Vatican.

To return to the sixteenth century: when Cardinal Sirleto ${ }^{2}$ was the General of the Basilian Order, his friend, Cardinal Alexander Farnese, was the commendatory abbot of Grotta Ferrata. Like Sirleto he was an ardent Hellenist, and. he set to work to replenish the library of his monastery.

It is probable that the original library of Grotta Ferrata had almost disappeared by the fifteenth century. In $143^{2}$ a certain Ambrose ${ }^{3}$ says that he visited it and found the books in it 'dissipata, disrupta, conscissa, putrida, ut miserabilem omnem faciem praeferrent'.

Bessarion, who was commendatory abbot in 1462 , seems to have improved matters, and given it many MSS ; and according to the catalogue of that year, published by Mgr. Batiffol ", the library now numbered I33 MSS, of which twenty probably belonged to the original collection and about fifty were servicebooks. Alexander Farnese still further added to the library, and had a new catalogue made. It was practically the second collection of Grotta Ferrata. But we must not look for it now in its old home. Probably in the days of Pius V, or at least before 1626, the whole collection of literary MSS, together with the catalogue made in 1575, was moved to the Vatican, where it forms a little group of MSS known as Codices Cryptenses-not to be confounded with the Codices Cryptenses of Dom Rocchi's catalogue of the present library of Grotta Ferrata. Here, then, -is another source from which we may pick out South Italian MSS. It is the last of what may be called the private collections which drew upon the South Italian libraries.

Bessarion, Gonzalo de Perez, Lascaris, Dandolo, Sirleto,

$1 \mathrm{Mgr}$. Batiffol has found at least two, Ottob. 178 and Ottob. 210.

2 L'Abbaye de Rossano p. 40.

- L'Abbaye de Rossano p. II 8.

3 La Vaticane p. 105. 
Mabillon, Alexander Farnese, these are the chief collectors whose work may perhaps be retraced; but there were doubtless many others, and by their means.it has come to pass that South Italian MSS are to be found all over Europe.

But at the end of the seventeenth century a new and final stage in the dispersal of the libraries was reached, and the whole of the remaining MSS were overhauled and made into four great collections.

This was the work of Pietro Menniti ${ }^{1}$. He was elected General of the Basilians in 1796 , and at once began his work.

He first desired to form a Codex Diplomaticus of the Basilian Order, and though he did not succeed in doing this he has left a mass of material in the Dossier Basiliani in the archives of the Vatican, which is unedited, but has been extensively used by Mgr. Batiffol.

In pursuit of his plan he collected all the bulls and charters of South Italy and Sicily into the libraries of S. Basil in Urbe (a foundation of the seventeenth century) in Rome, and S. Salvator's at Messina. He then turned to MSS, as distinguished from charters. These he dealt with under two heads: (I) Liturgical books, (2) Literary books. Those, of both classes, which he found in Sicily, were collected into the libraries of S. Salvator and S. Pietro d'Itala. Those which he found in Italy were placed either at Grotta Ferrata or in S. Basil in Urbe. The former library received the liturgical works, the latter the literary ones.

There are two questions which are important with regard to these collections of South Italian MSS:-

(I) From what monasteries are they drawn?

(2) Where are they to be found now?

The first question is answered by Mgr. Batiffol in his L'Abbaye de Rossano. He finds that the bulk of the MSS come from S. Mary of Patira and S. Elias of Carbo; that there are a few taken from S. John the Reaper of Stilo, S. Adrian, S. Pietro d'Arena, and S. Bartholomew of Trigona; the remaining monasteries probably had none to supply, and cannot be shewn to have supplied any.

The second question may be answered shortly. The MSS which were sent to Grotta Ferrata are still there-the third ${ }^{1}$ L'Abbaye de Rossano p. $4 \mathrm{I}$ A. 
library which the monastery has possessed ; for the first almost disappeared and the second was taken to Rome before 1623, and is now the Codices Cryptenses in the Vatican library. The MSS taken to S. Basil in Urbe were obtained in 1780 (Mgr. Batiffol thinks by purchase), by Pope Pius VI, and placed in the Vatican, where they are catalogued as Codices Basiliani.

Such are the outlines of the history of the libraries of the Basilian monasteries in South Italy.

The question which is of most interest to scholars is, whether it is possible to do anything towards reconstructing the old libraries?

I cannot believe that this is at all outside the bounds of possibilities. The truth is that our knowledge of Greek minuscule hands is not great, and the attention which has been given to the history of old libraries has been often confined to Latin MSS.

Roughly speaking, there are two criteria in attempting to reconstruct old libraries, which may be employed in the absence of definite information:-

(I) The character of the calligraphy.

(2) Indications of provenance in MSS.

Much is to be hoped from the study of characteristic South Italian hands. It is extremely easy to recognize the hand of the School of Nilus, and this is in itself enough for a beginning.

Mgr. Batiffol has established its characteristic nature, though I think he was wrong in connecting it with Capua ; but he only noted it in MSS of which he could trace the provenance by some other means. Considering his purpose, that was both right and natural ; but the process can now be reversed, and instead of using the provenance to define the calligraphy of a district, we can use the calligraphy to determine the provenance. In this way, a more or less complete list might be made of all the South Italian MSS in European libraries. It would perhaps be especially easy in the Escurial, where we have the researches of M. Graux to help us.

I am sanguine enough to believe that the mere possession of this list would not exhaust the gain to our knowledge of Greek palaeography. It is sometimes said that two Greek minuscules of the same age are far more like each other than two Latin MSS.

There is some truth in this, but to a great extent it is based on ignorance. It is as easy to tell a Greek MS of the School of Nilus as it is to tell a Latin MS by an Irish scribe; yet twenty 
years ago nobody could do the former, while there must have been hundreds of scholars who could tell Irish MSS when they saw them.

Greek palaeography has fallen behind Latin, and in some respects we have even lost knowledge once possessed.

For instance, there was, it is said, a Greek school for scribes at Nardo, in the heel of Italy, whose work, known as literae Neritinae, was described as superior to print ${ }^{1}$ : 'Sunt enim hae literae perpulcrae et castigatae et iis quibus nunc utuntur impressores Orientalibus ad legendum aptiores,' says de Ferrariis. I have tried in vain to find any one who knows what this hand is. A well-known German scholar recently described a MS as written in literae Neritinae; but when he was asked to give his reasons, it appeared that he had conceived literae Neritinae out of his inner consciousness of what de Ferrariis had meant!

I cannot resist the belief that there is still much to be done in the identification of local Greek hands, even though we may never be able to attain the degree of certainty which is possessed by Latin scholars; and certainly one of the ways by which this knowledge may be attained is by studying the MSS which come from the old Basilian foundations of South Italy.

The criterion furnished by signs of proveriance has been already used by Mgr. Batiffol ${ }^{2}$ to reconstruct the library of S. Mary's of Patira, and the same scholar has given us some invaluable material for continuing the task which he has begun, in the catalogues which he has found of the libraries of S. Elias of Carbo and S. Peter's of Arena.

It ought to be possible, by using these documents and the facts which are given above as to the history of the collections which drew on the libraries of South Italy, both to reconstruct several small collections which are now merged in the great European libraries, and to find in them the remains of the once famous libraries of the Basilian houses. As I' said before, this would be a task which would grow easier as it advanced; press marks and other details would become intelligible, and would help to write what would surely be an interesting chapter in the history of Greek libraries.

K. LAKE. 